\title{
POLA SEBARAN IKAN PADA MUSIM BARAT DAN PERALIHAN DI PERAIRAN UTARA JAWA TENGAH
}

\author{
Asep Priatna1) dan Mohammad Natsir'1) \\ 1) Peneliti pada Balai Riset Perikanan Laut, Muara Baru-Jakarta \\ Teregristrasi I tanggal: 13 Juli 2007; Diterima setelah perbaikan tanggal: 28 September 2007; \\ Disetujui terbit tanggal: 6 Nopember 2007
}

\begin{abstract}
ABSTRAK
Penelitian ini bertujuan untuk mempelajari perbedaan pola sebaran ikan pada musim barat dan peralihan di perairan utara Semarang sampai dengan Brebes, berdasarkan pada pengambilan contoh akustik dan oseanografi pada bulan Desember 2005 dan Mei 2006. Hasil menunjukkan secara spasial, pada musim barat di perairan utara Semarang sampai dengan Brebes kepadatan ikan pelagis lebih besar di daerah yang lebih dangkal yaitu sebelah selatan pada kedalaman $<40 \mathrm{~m}$, semakin ke tengah kepadatan semakin berkurang. Dilihat dari nilai target strength yang terdeteksi yaitu antara -60 sampai dengan $-50 \mathrm{~dB}$ bahkan didominasi oleh ikan -60 sampai dengan $-55 \mathrm{~dB}$, sasaran merupakan ikan pelagis kecil yang rata-rata mempunyai ukuran 4 sampai dengan $12,5 \mathrm{~cm}$. Pada musim peralihan sebaran kepadatan ikan pelagis kecil cenderung lebih merata dengan jumlah yang lebih rendah daripada jumlah ikan pada musim barat. Faktor pergerakan arah arus dan keberadaan sumber makanan yang lebih besar pada musim barat diduga merupakan penyebab perbedaan tersebut. Ikan pelagis kecil pada musim peralihan berukuran lebih besar dibandingkan ketika musim barat, dengan nilai target strength yang terdeteksi antara -60 sampai dengan -45 dB atau sekitar 4 sampai dengan $22 \mathrm{~cm}$ dan didominasi oleh ikan yang berukuran -55 sampai dengan $-50 \mathrm{~dB}$ atau sekitar 7 sampai dengan $12,5 \mathrm{~cm}$. Sebaran kepadatan Ikan demersal hampir merata pada ke-2 musim tersebut, pada musim peralihan kepadatan lebih rendah daripada musim barat. Ikan demersal pada musim barat terdiri atas ikan berukuran kecil ( -55 sampai dengan $-50 \mathrm{~dB}$ ) atau sekitar 7 sampai dengan $12,5 \mathrm{~cm}$ terutama di daerah pada kedalaman $<40 \mathrm{~m}$, semakin ke tengah ukuran semakin besar yaitu antara -50 sampai dengan - $45 \mathrm{~dB}$ atau sekitar 12,5 sampai dengan 22 $\mathrm{cm}$. Pada musim peralihan, ikan demersal dengan target strength -55 sampai dengan $-50 \mathrm{~dB}$ terdapat di kedalaman $<40 \mathrm{~m}$. Ikan demersal dengan ukuran -50 sampai dengan $-45 \mathrm{~dB}$ mendominasi periode ini. Pada kedalaman $>45 \mathrm{~m}$ terdeteksi ikan -45 sampai dengan $-35 \mathrm{~dB}$ yang berkisar 22 sampai dengan $70 \mathrm{~cm}$.
\end{abstract}

KATAKUNCl: $\quad$ akustik, ikan pelagis, ikan demersal, musim barat dan peralihan, Laut Jawa

ABSTRACT: The pattern of fish distributions at North West and intermonsoon in North of Central Java waters based on acoustic method. By : Asep Priatna and Mohammad Natsir

The aim of this study is to understood the difference of fish pattern distributions at North West and intermonsoon in North of Central Java waters, based on acoustic and oceanography sampling in December 2005 and May 2006. At North West monsoon, the density of pelagic fishes was more gathering in narrower areas $<40 \mathrm{~m}$, and low fish density was going to middle areas. Seen from target strength the value was detected about -60 to $-50 \mathrm{~dB}$ and it was dominated by fishes -60 to $-55 \mathrm{~dB}$, the targets for small pelagic fishes are about 4 to $12,5 \mathrm{~cm}$. At the intermonsoon, distribution of small pelagic fishes density tends to be flat, but fish density at this time was the lower than North West monsoon. The higly current direction and food source factor at North West monsoon may cause this difference. The size of small pelagic fishes at the intermonsoon was bigger than fishes at North West monsoon, which target strength value was detected about -60 to $-45 \mathrm{~dB}$ or 4 to $22 \mathrm{~cm}$ and dominated by fishes -55 to $-50 \mathrm{~dB}$ of about 7 to $12,5 \mathrm{~cm}$. The density distribution of demersal fishes almost flat at both monsoon. How ever at intermonsoon, the demersal fishes density was lower than that at North and West season. Demersal fishes at North West monsoon consisted of small fishes (-55 to -50 dB) with size of about 7 to $12,5 \mathrm{~cm}$ especially in narrow areas $<40 \mathrm{~m}$, and fish sizes the larger $(-50$ to -45 $d B$ or 12,5 to $22 \mathrm{~cm}$ ) were going to the middle areas. At intermonsoon, there were demersal fishes with target strength -55 to $-50 \mathrm{~dB}$ at $<40 \mathrm{~m}$. Demersal fishes with target strength -55 to $-50 \mathrm{~dB}$ were dominant at this time. At areas $>45 \mathrm{~m}$ it was detected fishes of -45 to $-35 \mathrm{~dB}$ target strength of about 22 to $70 \mathrm{~cm}$.

KEYWORDS: acoustic, pelagic fishes, demersal fishes, North and West monsoon, intermonsoon, Java Sea 


\section{PENDAHULUAN}

Iklim muson merupakan faktor yang menentukan sifat-sifat perairan Laut Jawa. Faktor lingkungan seperti faktor fisik, kimia, dan biologi merupakan salah satu faktor yang penting dalam perubahan sebaran dan kelimpahan ikan (Laevastu \& Hela,1970). Perairan Laut Indonesia yang beriklim tropis mempunyai keragaman spesies yang tinggi, dan masing-masing spesies tidak menempati ruang atau lapisan secara acak, ikan hidup berdasarkan pada ada kecocokkan dengan faktor lingkungan (Gunarso, 1998).

Pertukaran air secara musiman dengan Laut Flores menentukan pola penyebaran kelimpahan dan keberadaan ikan pelagis. Kelompok ikan oseanik dan neritik muda memasuki Laut Jawa mengikuti massa air bersalinitas lebih tinggi yang datang dari Timur. Sementara itu, kelompok ikan pantai cenderung tinggal di Laut Jawa sepanjang tahun (Sadhotomo \& Durand, 1997).

Pada musim barat, di perairan utara Jawa dominasi karakteristik kelimpahan fauna semi pelagis dan pelagis berada pada lapisan kedalaman 25 sampai dengan $45 \mathrm{~m}$. Pengelompokkan ikan pelagis semakin berkurang pada perairan lepas pantai. Hasil penelitian menunjukkan bahwa kepadatan di perairan sekitar Semarang terkadang tinggi karena ada pengaruh musim. Keberadaan ikan pelagis di perairan pantai utara Jawa sangat sempit, di mana sebagian kelompok ikan semi pelagis pada musim timur yang berada di bagian timur Laut Jawa bermigrasi ke arah pantai pada musim barat (Petit et al., 1997).
Penerapan metode akustik yang didukung oleh data lingkungan perairan, diharapkan dapat memberikan hasil pendugaan sebaran in situ kepadatan dan ukuran ikan pada periode musim yang berbeda.

\section{BAHAN DAN METODE}

Penelitian dilakukan di perairan utara Jawa Tengah. Survei yang pertama pada bulan Desember 2005 yang mewakili musim barat, dan yang ke-2 pada bulan Mei 2006 yang mewakili musim peralihan dari musim barat menuju musim timur (Gambar 1). Sarana penelitian yang digunakan adalah K.R. Bawal Putih.

Alat akustik yang digunakan adalah SIMRAD EK60 dengan frekuensi $120 \mathrm{KHz}$. Pengambilan data oseanografi dengan conductivity temperature and depth sea bird, data contoh ikan dengan pengoperasian bottom trawl. Untuk data plankton, larva, dan bentos digunakan planktonet, bonggonet, dan grab.

\section{Pengambilan Data} yaitu:

Data yang diperoleh selama periode pengamatan

1. Data akustik: area back scattering coefficient $\left(\mathrm{m}^{2}\right.$ $\mathrm{nmi}^{2}$ ) dan target strength $(\mathrm{dB})$.

2. Data oseanografi: arah arus, suhu, dan salinitas.

3. Data hasil tangkapan: distribusi ukuran panjang dan laju tangkap (kg per jam) ikan pelagis dan demersal tiap stasiun trawl.
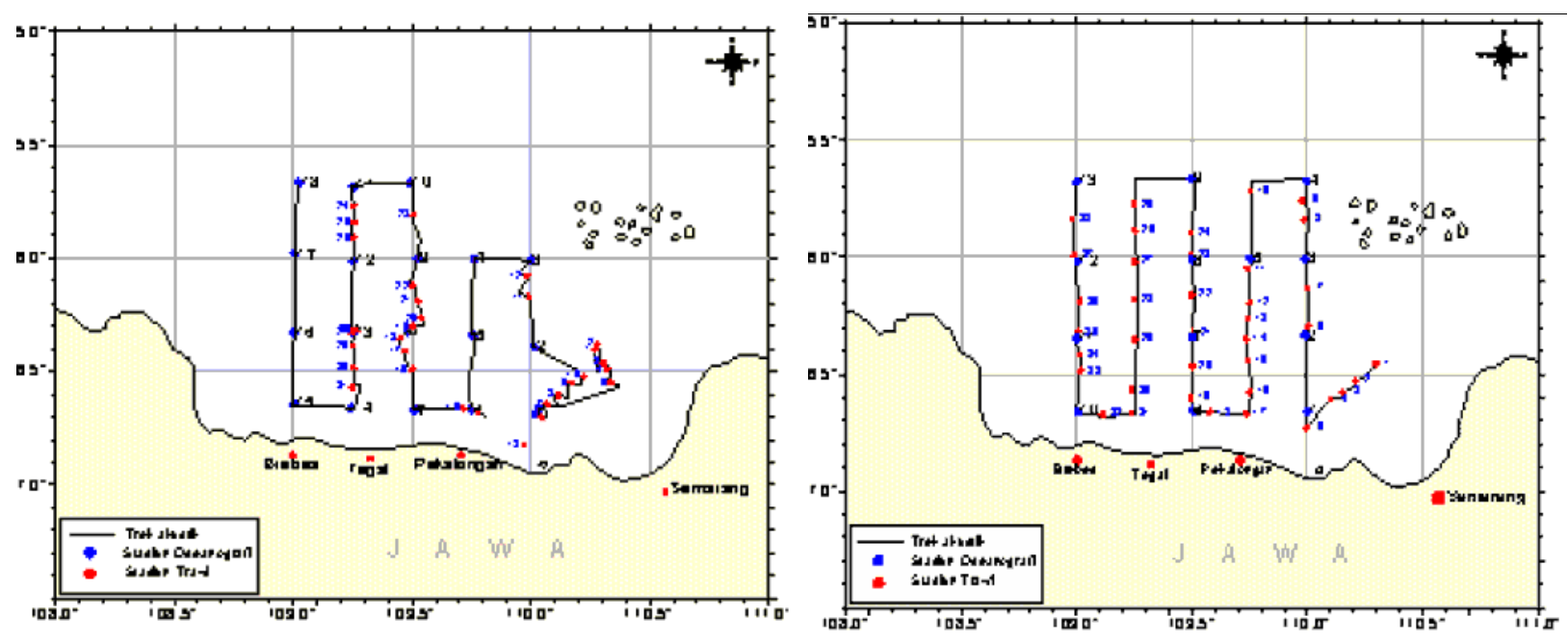

Gambar 1. Trek akustik dan posisi pengambilan contoh bulan Desember 2005 (a) dan bulan Mei 2006 (b). Figure 1. Acoustic track and sampling positions on December 2005 (a) and May 2006 (b). 
4. Digunakan juga data pendukung yaitu: kepadatan plankton, larva, dan bentos tiap stasiun pengambilan contoh.

Jaring trawl dioperasikan rata-rata 1 jam untuk setiap titik-titik pengambilan contoh, dengan kecepatan towing 3 knot. Pada bulan Desember 2005 dilakukan 31 pengambilan contoh sedangkan bulan Mei 2006 dilakukan 38 pengambilan contoh penangkapan.

Standar operasional pengambilan data mengikuti cara-cara baku, dan tidak ada perbedaan setting akuisisi terutama untuk data akustik pada 2 kali pengamatan tersebut.

\section{Pengolahan dan Analisis Data}

Sasaran yang terdeteksi oleh akustik pada kolom perairan dikatakan dalam nilai integrator area back scattering coefficient dengan satuan $\mathrm{m}^{2} \mathrm{nmi-}{ }^{2}$ dan sebaran nilai target strength yang menunjukkan variasi dari ukuran ikan dalam unit $\mathrm{dB}$.

Indeks kelimpahan digambarkan berdasarkan pada reverberasi akustik yang dikatakan dalam satuan $\mathrm{SA}\left(\mathrm{m}^{2} \mathrm{nmi}^{2}\right)$ pada setiap $0,1 \mathrm{nmi}$. Bentuk pengukuran lain seperti ekor $1.000 \mathrm{~m}^{-3}$ dan lain-lain, dianggap proporsional dengan satuan tersebut. Sehingga analisis cukup dilakukan terhadap pengukuran satuan SA.

Terdapat hubungan antara ukuran ikan dengan nilai target strength, tapi hubungan tersebut sangat bervariasi tergantung spesies. Pada umumnya untuk spesies ikan yang sama, makin besar ukuran ikan, maka makin besar nilai target strength (Johanesson \& Mitson, 1983). di mana:

$A=$ nilai target strength untuk $1 \mathrm{~cm}$ panjang ikan

Untuk menghindari bias pada permukaan transducer, maka pengolahan data akustik untuk pendugaan ikan pelagis dimulai dari kedalaman $5 \mathrm{~m}$. Sedangkan untuk ikan demersal $3 \mathrm{~m}$ dari dasar perairan.

Teknik analisis data dengan metode kriging. Hasil ditampilkan dalam bentuk sebaran horisontal spasial sehingga dapat dilihat pola sebaran secara geografis. Analisis meliputi interpretasi visual berbasis pada presentasi grafikal merupakan dasar bagi penafsiran data dan penyusunan informasi.

\section{HASIL DAN BAHASAN}

\section{Sebaran Kepadatan dan Ukuran Ikan Pelagis}

Berdasarkan pada sebaran spasial ikan pelagis pada Gambar 3 dan 6, maka diperoleh gambaran pola sebaran kepadatan dan ukuran dari ikan-ikan pelagis tersebut. Pengaruh kondisi perairan pada musim yang berbeda yaitu musim barat dan musim peralihan memperlihatkan pola sebaran ikan yang berbeda pula dari ke-2 musim tersebut (Sadhotomo \& Nurhakim, 2000). Kondisi musim di perairan Indonesia yang sangat dipengaruhi oleh sistem angin musim, sangat mempengaruhi pergerakkan arus terutama arus permukaan (Nontji, 1987).

Pada musim barat di perairan utara Jawa Tengah kepadatan ikan pelagis lebih tinggi di daerah yang lebih dangkal yaitu bagian selatan pada kedalaman $<40$ m (Gambar 2), semakin ke tengah menuju perairan yang lebih dalam, atau tepat ke arah timur laut jumlah semakin berkurang.

$T S=10 \log L+A$ $(1$

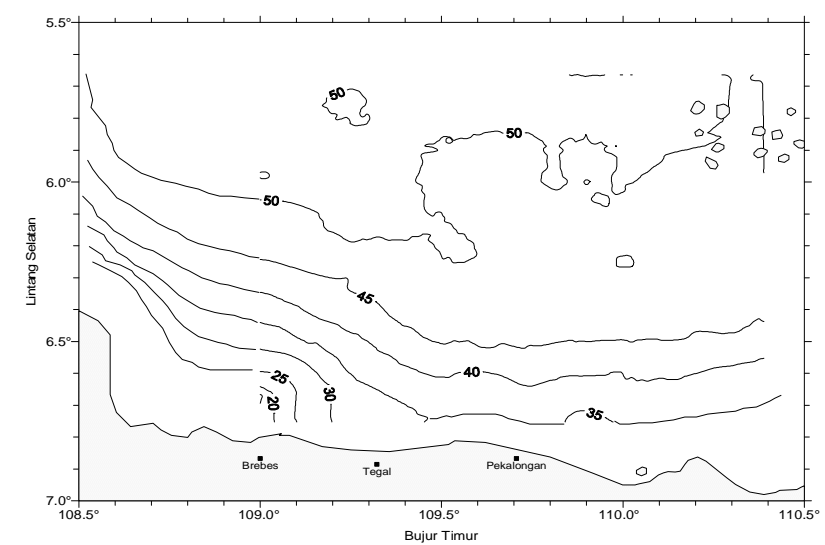

Gambar 2. Kontur kedalaman perairan pada lahan yang di survei.

Figure 2. Depth contour at sampling area. 
Distribusi laju tangkap menunjukkan bahwa pada bulan Desember 2005 yang mewakili musim barat, stok ikan pelagis kecil lebih banyak berada di perairan yang lebih dangkal (coastal), sedangkan pada bulan Mei 2006 stok ikan pelagis kecil lebih merata. Rendah laju tangkap pada bulan Desember, menunjukkan bahwa ukuran ikan pada musim barat lebih kecil dari pada ukuran ikan pada musim peralihan. Selain itu, kondisi alam di mana gelombang dan angin yang tinggi pada musim barat, merupakan salah satu kendala saat operasi penangkapan yang menentukan hasil tangkapan.

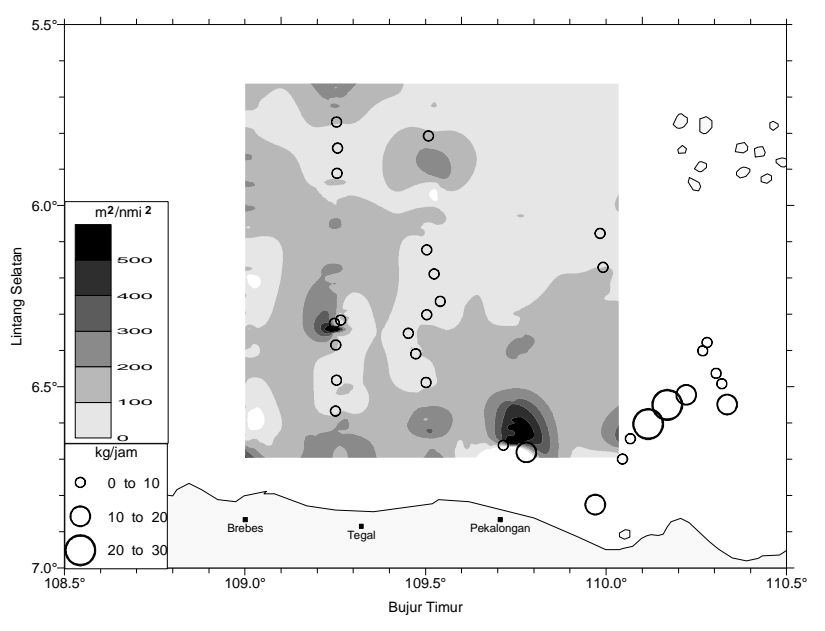

Dilihat dari nilai target strength yang terdeteksi yaitu antara -60 sampai dengan $-50 \mathrm{~dB}$ bahkan di dominasi oleh ikan - 60 sampai dengan $-55 \mathrm{~dB}$, maka dengan mengadopsi hubungan panjang ikan sama dengan 20 log target strength + konstanta (Foote, 1987), spesies-spesies tersebut merupakan ikan pelagis kecil yang rata-rata mempunyai ukuran sekitar 4 sampai dengan $12,5 \mathrm{~cm}$. Pola sebaran yang demikian diakibatkan pengaruh arus musim pada bulan Desember sampai dengan April yang mencapai puncak pada bulan Desember sampai dengan Pebruari yang dikenal dengan musim barat (Birowo, 1977).

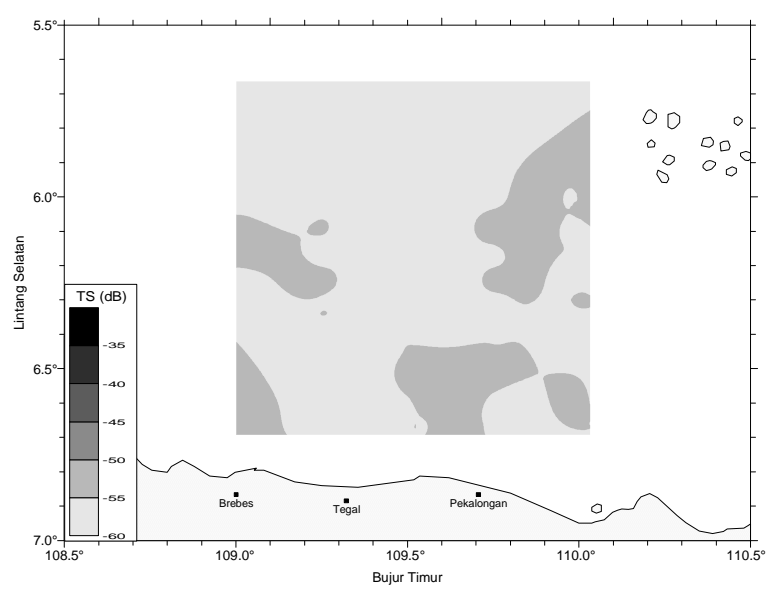

Gambar 3. Distribusi nilai SA dengan laju tangkap (a) dan distribusi nilai target strength (b) ikan pelagis pada musim barat.

Figure 3. Distributions of SA value with catch rates (a) and target strength distributions (b) for pelagic fishes at North West monsoon.

Pada musim barat, arus bergerak dari arah barat laut menuju tenggara (Gambar 4), kemudian bergerak menyusuri pantai utara Jawa ke arah timur, karena lokasi berada di selatan khatulistiwa, maka di bagian tengah arus mengalami pembelokan ke arah timur laut atau berlawanan dengan arah jarum jam (Wyrtki, 1961). Seperti yang ditunjukkan Gambar 3 di atas, pola sebaran ikan pelagis kecil mengikuti arah pergerakkan arus tersebut. Terlebih ukuran ikan yang rata-rata relatif kecil yang membentuk suatu gerombolan (schooling), sehingga cenderung bergerak mengikuti arus. Pada musim barat selain pengaruh faktor fisik yaitu arus, pola sebaran ikan pelagis tersebut didukung dengan keberadaan plankton dan larva ikan yang bergerak mengikuti arah arus, sehingga konsentrasi kepadatan lebih tinggi di sebelah selatan dengan kepadatan fitoplankton sekitar $250.000 \mathrm{sel} \mathrm{m}^{-3}$, zooplankton sekitar 5.000 ind. $\mathrm{m}^{-}{ }^{3}$ dan larva sekitar 2.000 per $1.000 \mathrm{~m}^{3}$ (Lampiran $1 \mathrm{a}, \mathrm{b}$, dan c). Sebagaimana diketahui bahwa keberadaan plankton dan larva ikan sebagai sumber makanan merupakan indikator keberadaan sumber daya ikan pelagis.

Pada musim barat, perubahan suhu, dan salinitas semakin tinggi ke arah dekat pantai (Gambar 5). Selain faktor pengenceran dari sebelah utara, variasi curah hujan sangat mempengaruhi kondisi salinitas tersebut (Manurung \& Simbolon, 1997). Kondisi suhu yang hangat, salinitas yang cocok serta sumber makanan yang melimpah merupakan faktor yang mendukung proses pemijahan ikan pelagis kecil. Hal ini, dibuktikan dengan kelimpahan plankton dan larva ikan yang tinggi di sebelah selatan, serta struktur ukuran ikan yang didominasi oleh ikan yang berukuran kecil.

Kondisi sebaliknya terjadi pada musim peralihan. Sebaran ikan pelagis kecil cenderung lebih merata, dengan kepadatan yang lebih rendah daripada musim barat. Hal tersebut, salah satunya dipengaruhi oleh keberadaan plankton dan larva sebagai sumber 
makanan, di mana penyebaran lebih merata dengan kepadatan lebih rendah daripada musim barat (Lampiran 1a, b, dan c). Kepadatan rata-rata fitoplankton hanya sekitar 15.000 sel $\mathrm{m}^{-3}$, zooplankton sekitar 1.000 ind. $\mathrm{m}^{-3}$ dan larva sekitar 300 per 1.000 $\mathrm{m}^{3}$ (Lampiran 1).

Penyebaran ikan yang cenderung merata pada musim peralihan, diakibatkan karena kondisi perairan yang relatif tenang dengan kecepatan arus yang relatif lebih kecil dibandingkan pada musim barat. Kondisi arus yang demikian disebabkan oleh arah angin tidak menentu pada musim peralihan, walaupun diakhir periode yaitu sekitar bulan Mei kondisi alam sudah dipengaruhi angin musim timur (Nontji, 1987). Pada periode ini aktivitas penangkapan ikan oleh nelayan di perairan utara Jawa meningkat, yang secara langsung mempengaruhi keberadaan atau stok ikan. Akibatnya, kepadatan ikan pelagis pada musim peralihan lebih sedikit dibandingkan pada musim barat.

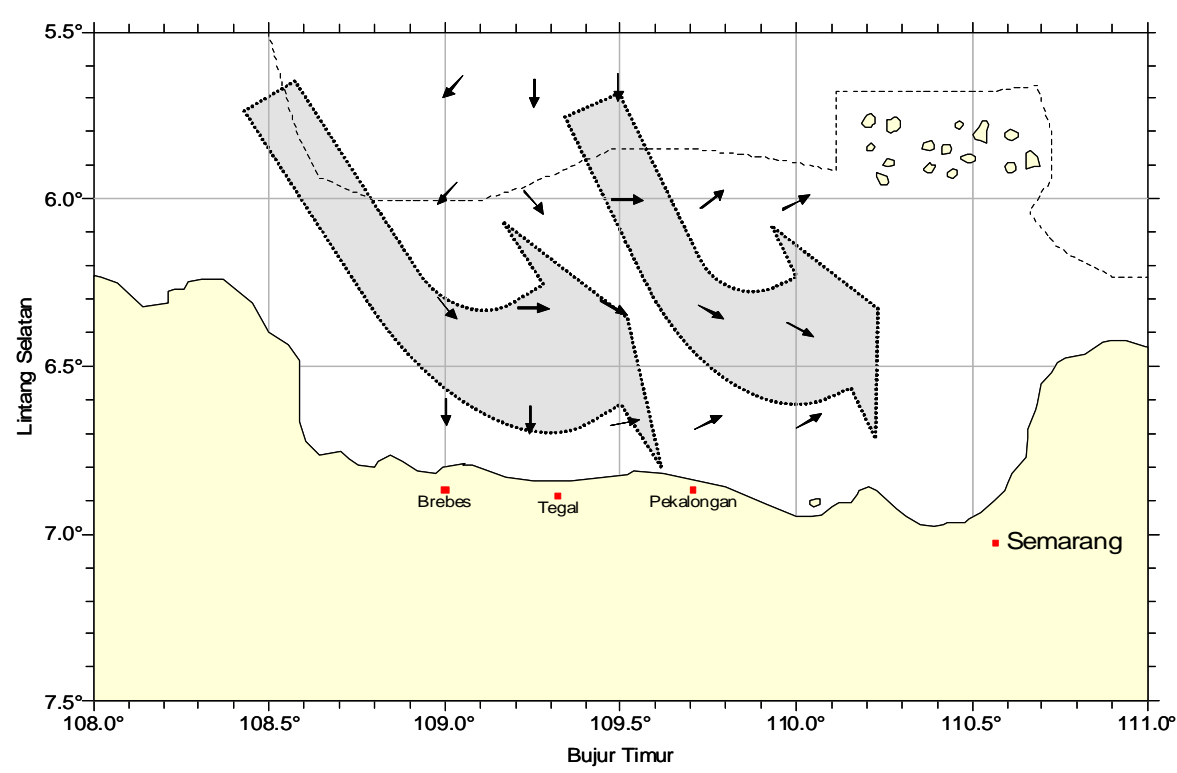

Gambar 4. $\quad$ Arah pergerakkan arus permukaan pada musim barat.

Figure 4. Current directions of sampling area at North and West monsoon
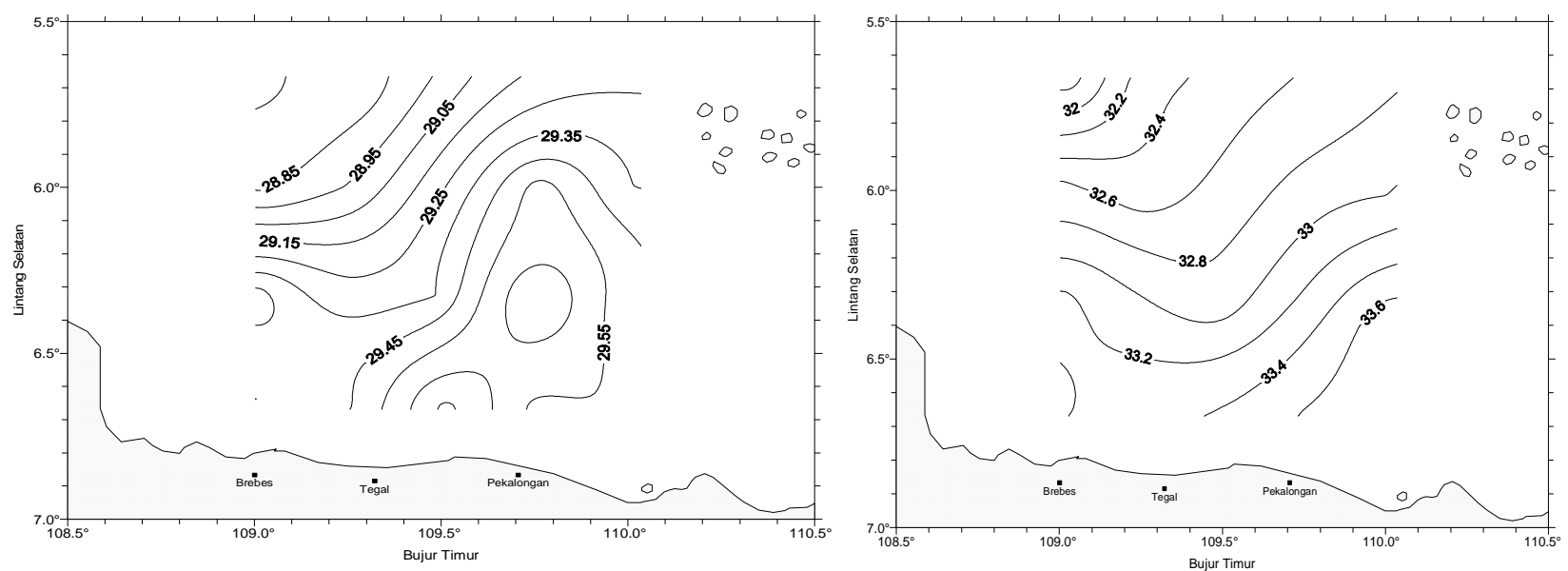

Gambar 5. Sebaran suhu (a) dan salinitas (b) pada musim barat.

Figure 5. Horizontal distribution of temperature (a) and salinity (b) at North West monsoon 
Ikan pelagis kecil pada musim peralihan berukuran lebih besar dibanding ketika musim barat. Nilai target strength yang terdeteksi antara -60 sampai dengan $45 \mathrm{~dB}$ atau sekitar 4 sampai dengan $22 \mathrm{~cm}$ dan didominasi oleh ikan yang berukuran - 55 sampai dengan $-50 \mathrm{~dB}$ atau sekitar 7 sampai dengan 12,5 $\mathrm{cm}$. Gambar 7 memperlihatkan perbandingan ukuran salah satu contoh ikan pelagis yang dominan tertangkap.
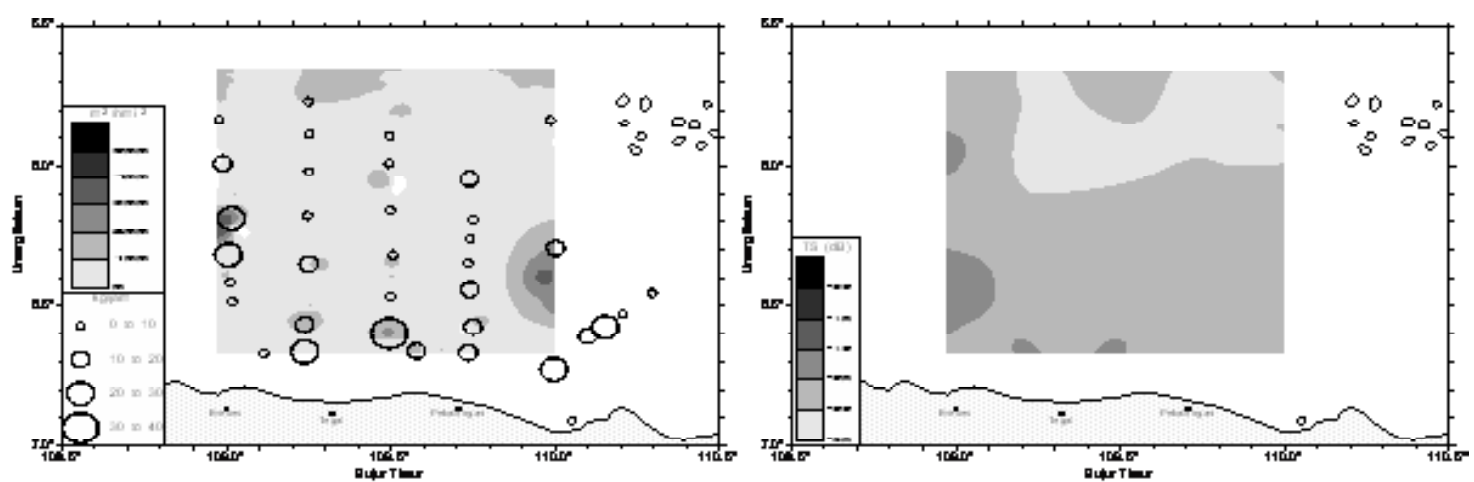

Gambar 6. Distribusi nilai SA dengan laju tangkap (a) dan distribusi nilai target strength (b) ikan pelagis pada musim peralihan.

Figure 6. Distributions of SA value with catch rates (a) and target strength distributions (b) for pelagic fishes at intermonsoon.

\section{Sebaran Kepadatan dan Ukuran Ikan Demersal}

Sebaran kepadatan Ikan demersal hampir merata pada ke-2 musim tersebut. Kepadatan pada musim peralihan lebih rendah daripada musim barat. Kelimpahan bentos yang jauh lebih tinggi pada musim barat dibanding musim peralihan (Lampiran 1d), merupakan salah satu penyebab. Rata-rata kepadatan bentos pada musim barat sekitar 16.000 ind. $\mathrm{m}^{3}$, sedangkan pada musim peralihan hanya 500 ind. $\mathrm{m}^{3}$. Kepadatan ikan demersal pada musim peralihan adalah sekitar $50 \%$ dari musim barat. Pada musim peralihan, penangkapan ikan di perairan utara Jawa meningkat, secara visual diketahui saat di lapangan di mana banyak ditemui aktivitas penangkapan oleh nelayan. Pada bulan Desember hanya terlihat beberapa nelayan yang beroperasi dekat pantai. Secara langsung, hal tersebut mempengaruhi stok ikan, akibatnya jumlah ikan demersal pada musim peralihan lebih sedikit dibandingkan pada musim barat.
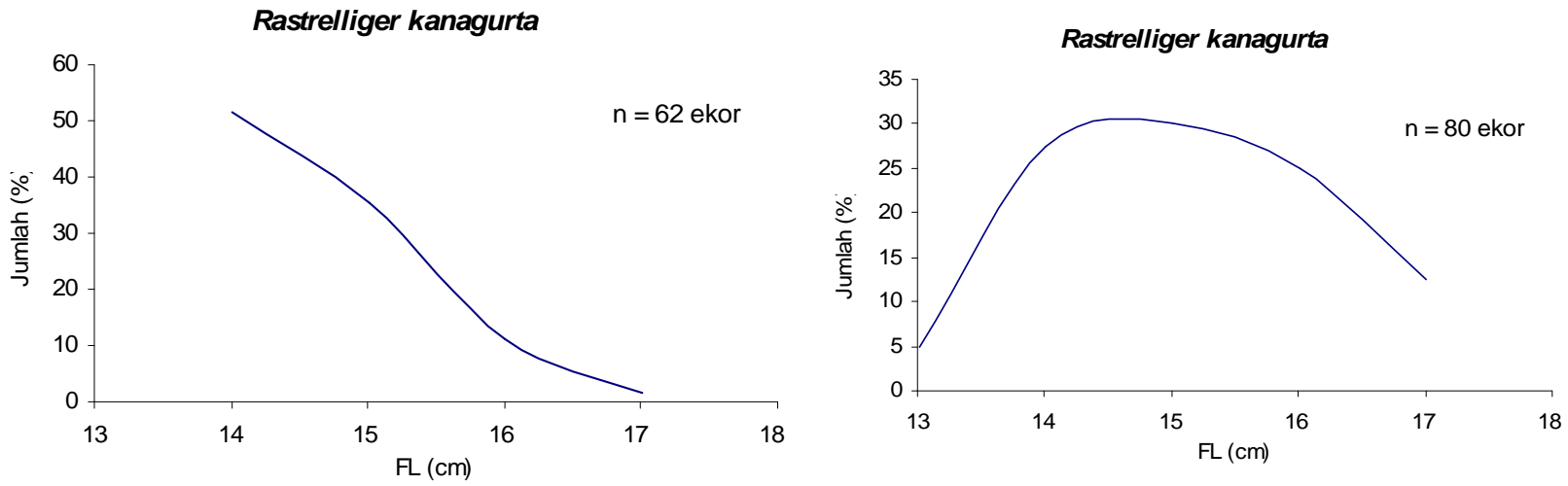

Gambar 7. Distribusi ukuran panjang contoh ikan pelagis yang dominan tertangkap pada bulan Desember 2005 (a) dan Mei 2006 (b).
Figure 7. Distributions of length frequency for pelagic fishes sample on Desember 2005 (a) and Mei 2006 (b).

Rendah laju tangkap pada bulan Desember, menunjukkan bahwa ukuran ikan pada musim barat lebih kecil daripada ikan di musim peralihan, walaupun kepadatan ikan demersal pada waktu musim barat hampir 2 kali kepadatan ikan pada musim peralihan.
Ditambah kondisi perairan yaitu gelombang dan angin yang tinggi pada musim barat, merupakan salah satu kendala saat operasi penangkapan yang menentukan hasil tangkapan. Gambar 8 menunjukkan keberadaan ikan demersal yang hampir merata pada lahan yang 
disurvei di mana laju tangkap tiap stasiun trawl menyebar secara acak.

Ikan demersal pada musim barat terdiri atas ikan berukuran kecil (-55 sampai dengan $-50 \mathrm{~dB}$ ) atau sekitar 7 sampai dengan $12,5 \mathrm{~cm}$ terutama di daerah pada kedalaman $<40 \mathrm{~m}$, semakin ke tengah ke arah yang lebih dalam ukuran semakin besar yaitu -50 sampai dengan $-45 \mathrm{~dB}$ atau sekitar 12,5 sampai dengan $22 \mathrm{~cm}$. Pada musim peralihan, ikan demersal dengan target strength - 55 sampai dengan $-50 \mathrm{~dB}$ terdapat pada kedalaman $<40 \mathrm{~m}$. Ikan berukuran -50 sampai dengan $-45 \mathrm{~dB}$ mendominasi periode musim tersebut (Gambar 9).

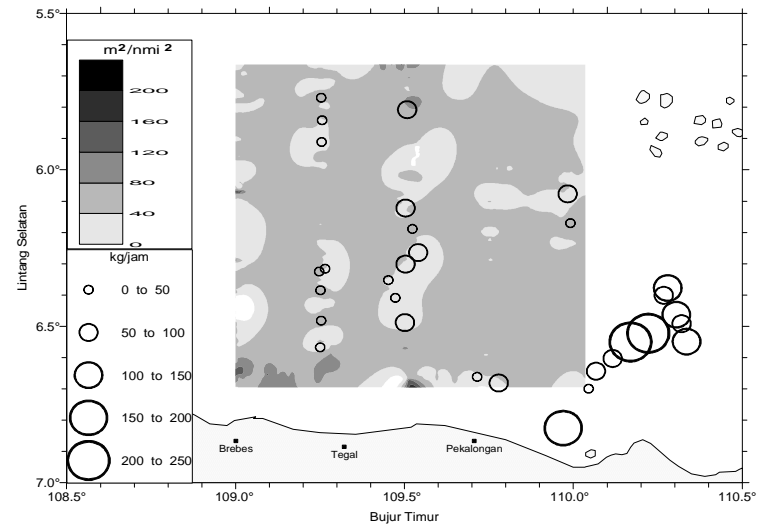

Saat musim peralihan, pada kedalaman $>45 \mathrm{~m}$ terdeteksi ikan dengan nilai target strength -45 sampai dengan $-35 \mathrm{~dB}$ atau 22 sampai dengan $70 \mathrm{~cm}$, Berdasarkan pada hasil tangkapan, jenis $L$. malabaricus, L. vitta, N. japonicus, dan S. rubrum terdapat pada lahan tersebut. Distribusi ukuran panjang ikan $>50 \%$ yang tertangkap adalah $\geq 12,5 \mathrm{~cm}$. Berdasarkan pada data akustik jenis-jenis ikan demersal dengan ukuran tersebut tidak mendominasi di lahan ini, sebab frekuensi target strength menunjukkan $\mathrm{TL} \geq 12,5$ adalah $<50 \%$ (Gambar 10$)$.

Gambar 8. Distribusi nilai SA dan laju tangkap ikan demersal pada musim barat (a) dan musim peralihan (b).

Figure 8. Distributions of SA value and catch rates) for demersal fishes at North West monsoon (a) and intermonsoon (b).
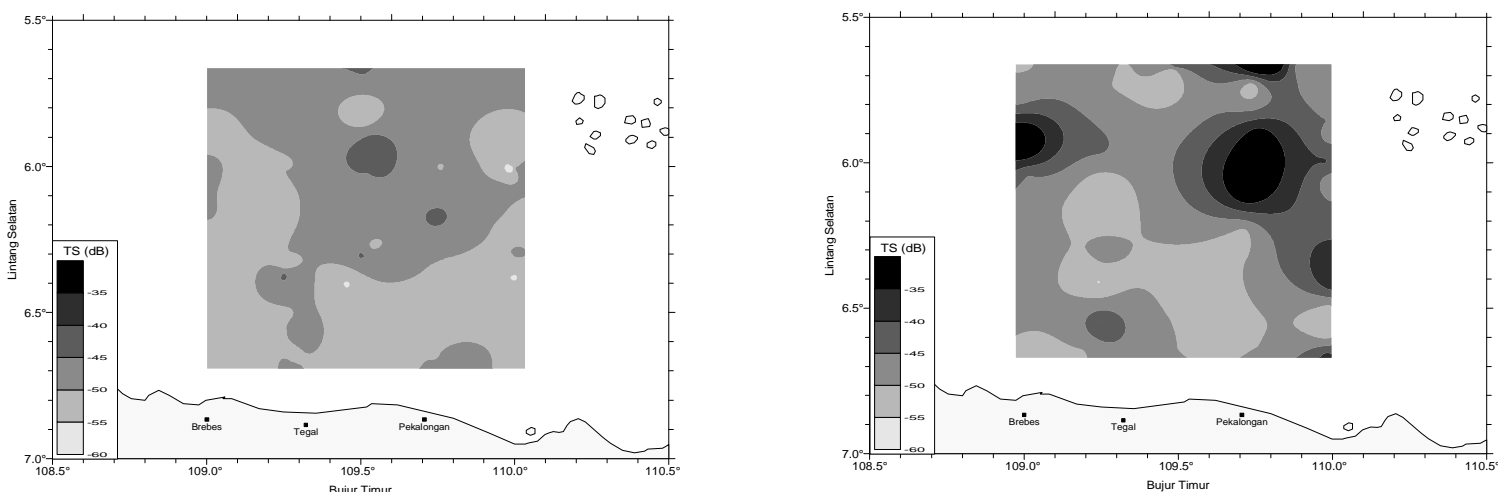

Gambar 9. Distribusi nilai target strength (dB) ikan demersal pada musim barat (a) dan musim peralihan

Figure 9. Distribution of target strength value (dB) for demersal fishes at North West monsoon (a) and intermonsoon (b). 


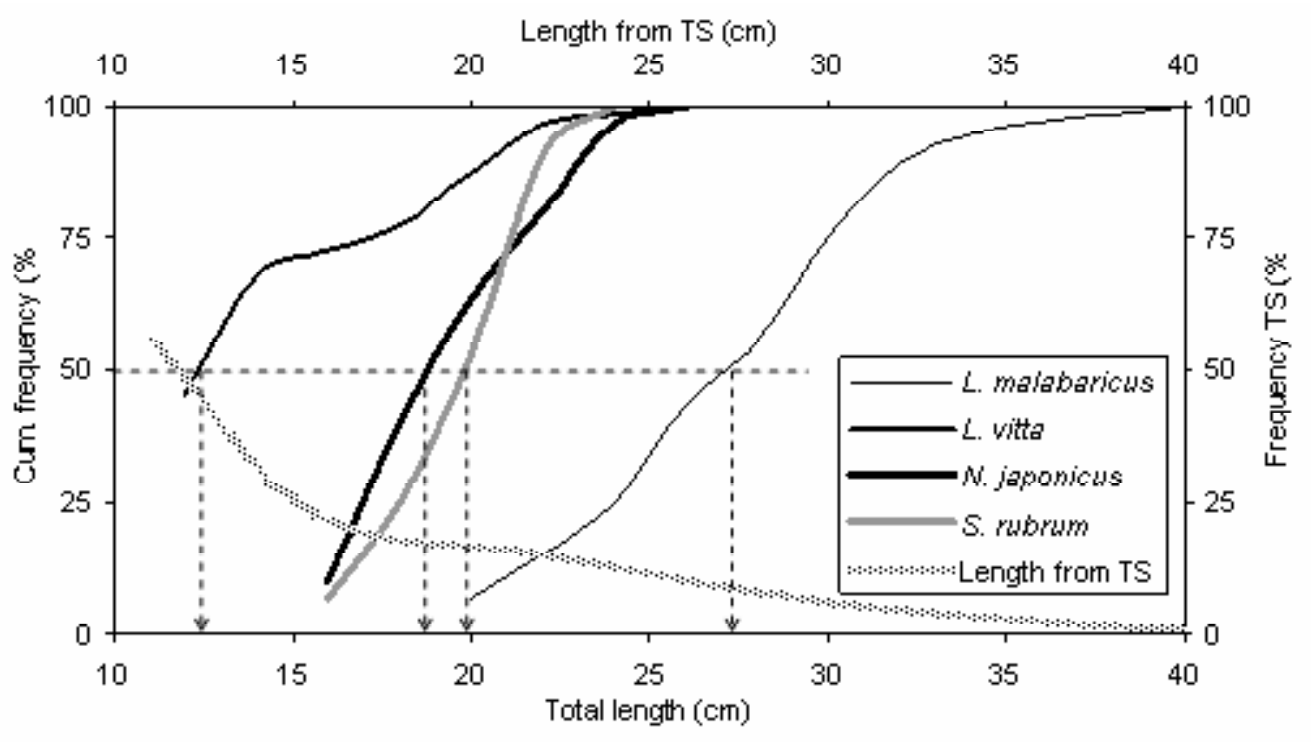

Gambar 10. Persentase frekuensi kumulatif $T L(\mathrm{~cm})$ beberapa jenis ikan demersal yang tertangkap terhadap persentase frekuensi TL $(\mathrm{cm})$ hasil konversi akustik pada stasiun traw/11, 12, dan 21 pada bulan Mei 2006.

Figure 10. Percentage of $T L(\mathrm{~cm})$ cumulative frequency for demersal fishes sample versus percentage of TL (cm) from acoustic in trawl station 11,12, and 21 on Mei 2006.

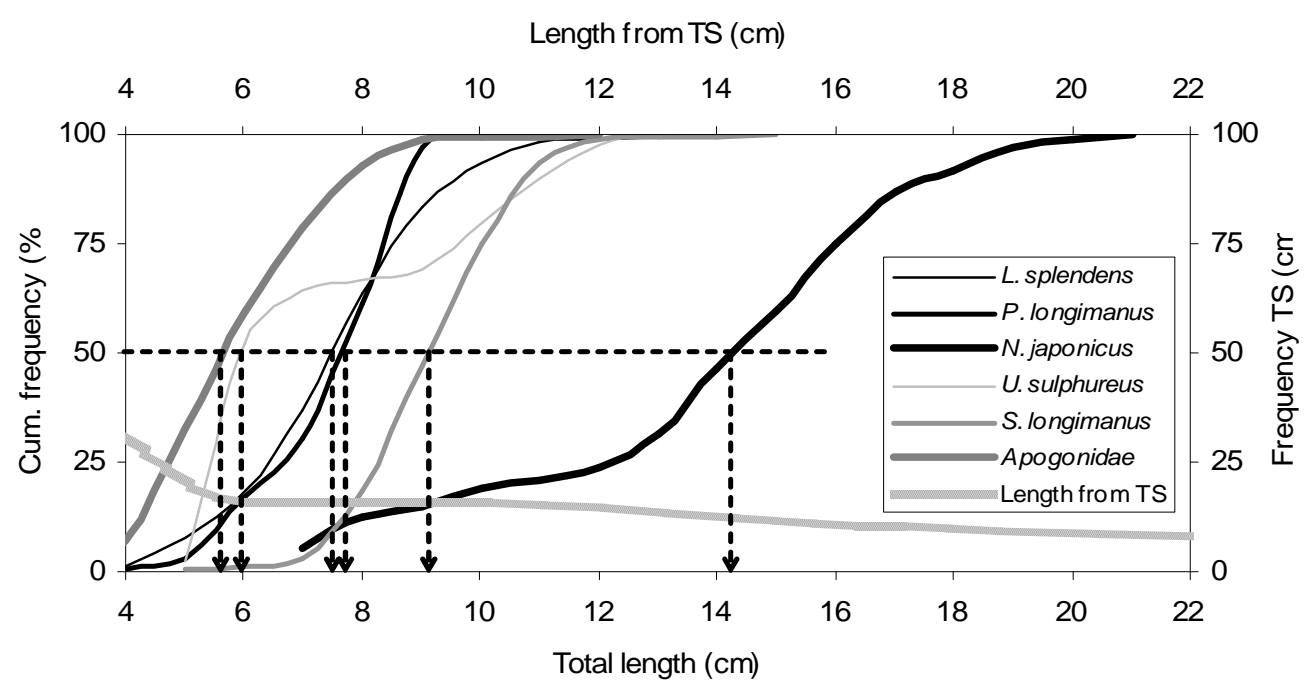

Gambar 11. Persentase frekuensi kumulatif TL $(\mathrm{cm})$ beberapa jenis ikan demersal yang dominan tertangkap terhadap persentase frekuensi $\mathrm{TL}(\mathrm{cm})$ hasil konversi akustik pada bulan Desember 2005.

Figure 11. Percentage of $T L(\mathrm{~cm})$ cumulative frequency for demersal fishes sample versus percentage of $T L(\mathrm{~cm})$ from acoustic on December 2005

Untuk ukuran ikan pada ke-2 musim, baik data tangkapan maupun data akustik menunjukkan bahwa struktur ukuran ikan demersal pada musim barat (Gambar 11) lebih kecil daripada musim peralihan (Gambar 12). Bahkan pada musim peralihan tertangkap ikan berukuran besar dari jenis Lutjanidae, hasil data akustik mulai terdeteksi ikan berukuran lebih besar daripada ukuran pada musim barat. Berdasarkan pada data tangkapan, ikan demersal di perairan utara Jawa Tengah didominasi jenis $L$. splendens, $P$. longimanus, $N$. japonicus, $U$. sulphureus, S. longimanus, S. micropectoralis, dan Apogonidae. 


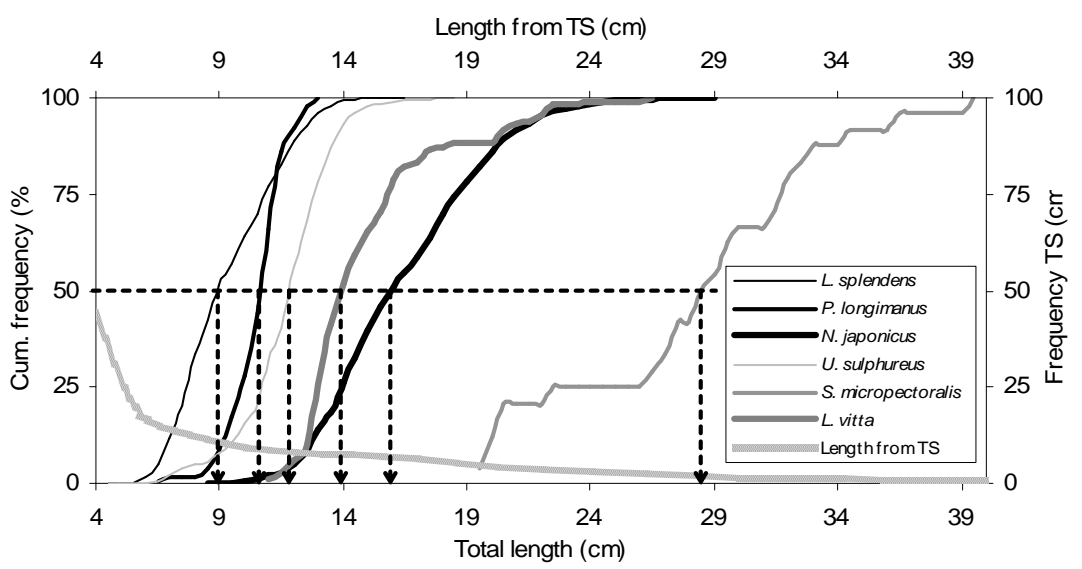

Gambar 12. Persentase frekuensi kumulatif $\mathrm{TL}(\mathrm{cm})$ beberapa jenis ikan demersal yang dominan tertangkap terhadap persentase frekuensi TL (cm) hasil konversi akustik pada bulan Mei 2006.

Figure 12. Percentage of TL $(\mathrm{cm})$ cumulative frequency for demersal fishes sample versus percentage of $T L(\mathrm{~cm})$ from acoustic on May 2006

\section{KESIMPULAN}

1. Kepadatan ikan pelagis kecil di perairan utara Jawa Tengah pada musim barat lebih besar di sebelah selatan yaitu perairan dangkal. Semakin ke tengah atau ke arah utara, kepadatan semakin berkurang. Selain faktor arus yang mendorong pergerakkan ikan pelagis kecil ke arah selatan, sumber makanan yaitu plankton dan larva yang melimpah di sebelah selatan atau daerah dangkal karena terbawa arus merupakan faktor pendukung bagi penyebaran dan kelimpahan ikan.

2. Pada musim peralihan, kepadatan ikan pelagis kecil cenderung merata sebab kecepatan arus yang tidak begitu kuat dan distribusi makanan yang lebih merata dengan kelimpahan lebih rendah daripada musim barat. Diduga hal ini, mendorong ikan pelagis kecil untuk bermigrasi ke berbagai arah.

3. Distribusi ikan demersal cenderung merata pada ke-2 musim. Kepadatan ikan demersal pada musim barat jauh lebih besar daripada musim peralihan. Faktor kelimpahan bentos yang merupakan salah satu sumber makanan ikan demersal, pada musim barat jauh lebih besar daripada musim peralihan.

4. Hasil deteksi akustik, rata-rata struktur ukuran ikan pelagis kecil dan demersal pada musim barat lebih kecil dibanding musim peralihan. Ikan pelagis kecil pada musim barat didominasi oleh ukuran 4 sampai dengan $7 \mathrm{~cm}$, sedangkan musim peralihan didominsi ikan berukuran 7 sampai dengan 12,5 $\mathrm{cm}$. Ikan demersal pada musim barat didominasi oleh ukuran 7 sampai dengan $12,5 \mathrm{~cm}$, sedangkan musim peralihan didominsi ikan berukuran 12,5 sampai dengan $22 \mathrm{~cm}$.

5. Kondisi perairan yang relatif tenang dan struktur ukuran ikan yang lebih besar pada musim peralihan merupakan pilihan bagi nelayan pantai utara Jawa untuk melakukan penangkapan, meski demikian kepadatan ikan pada musim peralihan lebih rendah daripada musim barat.

6. Makalah ini belum sampai dengan seberapa banyak kelimpahan atau biomassa ikan dari ke-2 musim tersebut. Aktifvitas penangkapan untuk ikan demersal, hendak bergeser ke perairan yang lebih dalam yaitu $>45 \mathrm{~m}$ karena diduga terdapat ikan demersal yang berukuran besar sekitar 20 sampai dengan $70 \mathrm{~cm}$.

\section{PERSANTUNAN}

Kegiatan dari hasil riset bioekologi dan pendugaan stok sumber daya ikan pelagis dan demersal di perairan utara Jawa, T.A. 2005-2006, di Balai Riset Perikanan Laut-Muara Baru, Jakarta.

\section{DAFTAR PUSTAKA}

Birowo, S. 1977. Sifat oseanografi permukaan laut dalam Kondisi lingkungan pesisir dan laut Indonesia. Penyunting K. Ronimuhtarto \& S. S. Thoyib. Lembaga Oseanologi Nasional. Lembaga Ilmu Pengetahuan Indonesia. Jakarta.

Foote, K. G. 1987. Fish target strength for use in echo integration surveys. Journal Acoustic Soc. Am. 82 (3): 981-987. 
Gunarso, W. 1998. Tingkah laku ikan dalam hubungannya dengan alat, metode, dan taktik penangkapan. Jurusan PSP. Fakultas Perikanan. Institut Pertanian Bogor. Bogor.

Johannesson, K. A. \& R. B. Mitson. 1983 Fisheries acoustic a pratical manual for aquatic biomass estimation. FAO. Fisheries Tech. Pop. Roma. 249 p.

Laevastu T. \& Hela I. 1970. Fisheries oceanography. Fishing News (Books) Ltd. London.

Manurung D. \& D. Simbolon. 1997. Spatial distribution of fish density in relation to environmental factors in Makassar Strait waters. Proceeding of the Acoustics Seminar AKUSTIKAN II. Jakarta. 143156.

Nontji, A. 1987. Laut Nusantara. Penerbit Djambatan. Jakarta.
Petit D., Cotel P., \& Nugroho D. 1997. Densities and behaviour of pelagic fish population along the Java and Sumatera coast in wet season. Proceeding of the Acoustics Seminar AKUSTIKAN II. Jakarta. 91-106.

Sadhotomo, B. \& J. R Durand. 1997. General feature of Java Sea ecology. Proceeding of the Acoustics Seminar AKUSTIKAN II. Jakarta. 43-53.

Sadhotomo, B. \& S. Nurhakim. 2000. Keterkaitan faktor oseanografi dengan sumber daya ikan pelagis. Bagian I: Deskripsi Faktor Fisik, Abiotik, dan Penyebaran Agregasi Akustik di Laut Flores. Jurnal Penelitian Perikanan Indonesia. Vol.6 No.34. Hal.1-9.

Wyrtki, K. 1961. Physical oceanography of the southeast Asian water. NAGA Report Vol.2. Scripps Inst. Oceanography. The University of California. 